\title{
ANALYSIS OF COMPETITIVENESS AND EXPORT TRENDS OF INDONESIAN COCOA TO THE FIVE DESTINATION COUNTRIES FOR 2010-2019
}

\author{
Nabilla Pratya Augustin*, Edy Prasetyo, Siswanto Imam Santoso \\ Diponegoro University, Indonesia \\ *corresponding author: nabilapratya@gmail.com
}

\begin{abstract}
This study aims to analyze the competitiveness of Indonesian cocoa exports to five destination countries, namely China, Germany, Malaysia, Singapore, and USA and to analyze the trend of Indonesian cocoa exports for the forecasting of the next 5 years. The data source used is secondary data in the form of export value and volume from 2010-2019 which is sourced from uncomtrade. Data analysis methods used are RCA, EPD, and linear trend analysis. The results showed that the comparative analysis of the RCA method for the commodities of Indonesian cocoa beans, cocoa butter, cocoa paste, cocoa powder in 20102019 has an RCA > 1 which means that it is competitive and has a comparative advantage in destination countries. Based on a competitive analysis using the EPD method, the commodity of Indonesian cocoa beans, cocoa butter, cocoa paste, and cocoa powder in 2010-2019 have EPD retreat and falling star values. Based on linear trend analysis, the export value of Indonesian cocoa beans in 2020-2024 is predicted to continue to decline, cocoa butter and cocoa powder in 2020-2024 is predicted to continue to increase, and cocoa paste in 2020-2024 is predicted to increase and later decrease.
\end{abstract}

Keywords: Competitiveness, Export, EPD, RCA, Trend

http://dx.doi.org/10.21776/ub.agrise.2021.021.3.6

Received 19 March 2021

Accepted 25 July 2021

Available online 31 July 2021

\section{INTRODUCTION}

Cocoa is one of the agricultural commodities in the plantation sub-sector that has an important role in economic activity in Indonesia. Cocoa is also one of Indonesia's export commodities which is quite important as a foreign exchange earner apart from oil and gas. It is one of the leading national commodity export commodities that contributed the third largest foreign exchange, amounting to the US $\$ 1.2$ billion after palm oil and rubber, it shows that cocoa plays a significant role in improving the economy (Hasibuan et al., 2012). In 2017, Indonesia was the third-largest cocoa producer and exporter in the world after Ghana and Ivory Coast (BPS, 2018). However, most of Indonesia's cocoa production is unfermented beans and most of the export is still in the form of dry cocoa beans (Hasibuan et al., 2012).

Minister of Finance Regulation No. 67 / PMK.011 / 2010 stipulates that starting in 2010,
Indonesia will implement a policy of export duty for cocoa beans up to $15 \%$. This regulation aims to improve the domestic cocoa processing industry to increase the export of processed cocoa products that are competitive. Since 2011 there has been a change in the composition of Indonesian cocoa exports where exports of processed products have increased while cocoa beans have decreased (Suryana et al., 2014). Indonesian cacao exports both in the form of beans and processed must have competitiveness in the form of comparative and competitive advantages to remain competitive, even are in the international market (Hasibuan et al., 2012).

Countries with a higher comparative advantage and competitive advantage will have the ability to dominate the international market in free trade conditions (Ghozy et al., 2017). One of the efforts that can be made to increase exports is by increasing the competitiveness of these export products. Competitiveness is a general concept in economics 
that refers to the commitment to market competition with its success in international competition (Kiranta and Meydianawathi, 2014). Growth trends need to increase along with competitiveness. The increasing long-term growth trend reflects long-term changes in the level of competitiveness of these products in global trade. The trend of increasing Indonesian cocoa exports and world cocoa consumption shows that the potential for the cocoa market is still high in the international market (Amalina et al., 2018).

\section{RESEARCH METHODS}

Cocoa is one of the plantation crops with abundant production. It has the potential to make cocoa Indonesia's leading export. Regulations regarding restrictions on export duty policies for cocoa beans provide opportunities for processed cocoa to develop to increase the export value of processed cocoa in the international market. This is following Permenkeu No. 67 / PMK.011 / 2010 that aims to grow the cocoa processing industry in the country and increase the export of processed cocoa products that are competitive. Competitiveness is needed to see the ability to compete with other exporting countries and to compare cacao beans and processed cocoa that is competitive in the international market and trends are needed to see trends in cocoa exports in the future.

\section{Data Collection}

The data used in this study is secondary data in the form of panel data consisting of cross-section data in the form of export value and volume of five export destination countries, China, Germany, Malaysia, Singapore, and the USA as well as timeseries data for 10 years, from 2010 to the year 2019. The object of the research were cocoa in the form of cocoa beans with code 180100 , cocoa butter with code 180400 , cocoa powder with code 180500 , and cocoa paste with code 180320 . The data was obtained from the Ministry of Agriculture, Central Bureau of Statistics (BPS), Ministry Trade, and the UN Comtrade website. Other data sources are books, journals, theses related to export competitiveness which are then processed systematically and objectively.

\section{Data Analysis}

The data analysis method used in this research is descriptive quantitative. Estimation of the competitiveness of Indonesian cocoa beans and processed exports was carried out using Revealed Comparative Advantage (RCA) and Export Product Dynamic (EPD) analysis. Indonesian cocoa export trends for the next 5 years forecast using Linear Trend analysis. The results of the calculation of RCA, EPD, and Linear Trend Analysis will be described using the theory of the analysis tool. In calculating the data, researchers used the Microsoft Excel 2010 application on Windows 10 and Minitab for Windows.

$$
\begin{aligned}
& \text { Formula of } \mathrm{RCA}=\frac{\mathrm{Xij} / \mathrm{Xit}}{\mathrm{Wj} / \mathrm{Wt}} \\
& \text { In which : }
\end{aligned}
$$

$\mathrm{Xij} \quad=$ Export value of commodity $\mathrm{i}$ from country $\mathrm{j}$ year to $\mathrm{t}$ to the destination country (US \$)

$\mathrm{Xit}=$ total export value of country $\mathrm{j}$ to destination country (US \$)

$\mathrm{Wj} \quad=$ world export value of commodity $\mathrm{i}$ to destination country (US \$)

$\mathrm{Wt}=$ total value of world exports to destination countries (US \$)

The value of RCA> 1 means that a country has a comparative advantage over the world average so that the commodity has strong competitiveness, while the value of RCA $<1$ means that a country does not have a comparative advantage over the world average so that the commodity has weak competitiveness.

EPD formula :

X-axis: Growth of Indonesia's Export Market Share

$$
\frac{\sum_{t=1}^{t}\left(\frac{X i j}{W i j}\right) t \times 100 \%-\sum_{t=1}^{t}\left(\frac{X i j}{W i j}\right) t-1 \times 100 \%}{T}
$$

Y-axis: Growth in the market share of Indonesian products or commodities

$$
\frac{\sum_{t=1}^{t}\left(\frac{X t}{W t}\right) t \times 100 \%-\sum_{t=1}^{t}\left(\frac{X t}{W t}\right) t-1 \times 100 \%}{T}
$$

In which :

$\mathrm{Xij}=$ The export value of Indonesian cocoa commodities to the destination country (US \$)

$\mathrm{Xt}=$ The total value of Indonesia's exports to the destination country (US \$)

Wij = World cocoa export value of destination countries (US \$)

$\mathrm{Wt}=$ Total value of world exports to destination countries (US \$)

$\mathrm{T}=$ Number of years analyzed $(\mathrm{t})$

Which is to determine the competitiveness based on the EPD method of a product can be seen where the position of competitiveness will be in one of the quadrants.

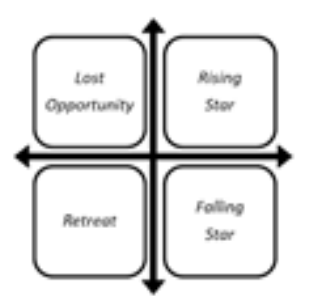

Figure 1. EPD Matrix 
Rising Star is an ideal market position aiming to gain the highest share of exports. Lost Opportunity is associated with a decline in market share in dynamic products. This condition is the least desirable because of the loss of export share opportunities for dynamic commodities in the world market. The Falling Star condition is also undesirable even though it is not like the Lost Opportunity condition because its market share is increasing even though it is not a dynamic product in the world market. Retreat means the product is no longer wanted on the market. However, it can be desirable again if the movement is away from stagnant products and moves closer to increasing dynamic products.

Linear Trend Analysis Method where:

$\mathrm{Y}=\mathrm{a}+\mathrm{b} \mathrm{X}$

Information:

$\mathrm{Y}=$ Data of cocoa export volume (tonnes) which is time series data

$\mathrm{X}=$ Export time

$\mathrm{a}=$ The trend value at time $\mathrm{X}=0$

$\mathrm{b}=$ trend-line direction coefficient

The formula developed from the linear function is obtained by the values of $a$ and $b$ with the formula:

$$
\begin{aligned}
& \mathrm{a}=\frac{\sum \mathrm{yi}}{n} \\
& \mathrm{~b}=\frac{\sum X i Y i}{X \boldsymbol{i}^{2}}
\end{aligned}
$$

\section{RESULTS AND DISCUSSION}

Cocoa has a strategic role in Indonesia's economy, one of which is the third-largest contributor to foreign exchange in the plantation sector after oil palm and rubber. Since the Minister of Finance Regulation No. 67 / PMK.011 / 2010, starting 2010 Indonesia implemented a policy of export duty for cocoa beans up to $15 \%$, so exports are not only focused on cocoa beans but also processed cocoa such as cocoa butter, cocoa paste, and cocoa powder. One of the efforts that can be made to increase cocoa exports is to increase the competitiveness of cocoa exports. Export competitiveness is the ability of a commodity to enter a foreign market which then can maintain that market. Competitiveness cannot be separated from trends as projections for the future. Cocoa export trends are needed to plan the possibilities for the future by looking at how the development of Indonesian beans and processed cocoa exports based on data on the number of cacao exports to the world. Export competitiveness and trends are necessary to analyze because they can be important information, especially in determining the right strategy to compete with other countries.

\section{Revealed Comparative Advantage (RCA)}

Table 1. Value of RCA Cocoa Beans Indonesia in export destination countries in 2010-2019

\begin{tabular}{cccccc}
\hline \multirow{2}{*}{ Tahun } & \multicolumn{5}{c}{ Nilai RCA } \\
& Malaysia & Singapura & China & Jerman & USA \\
\hline 2010 & 13,99 & 8,50 & 50,23 & 14,28 & 30,84 \\
2011 & 8,17 & 6,95 & 12,01 & 0,33 & 2,76 \\
2012 & 5,61 & 7,24 & 6,84 & 0,39 & 0,06 \\
2013 & 8,34 & 7,49 & 12,70 & 0,28 & 2,07 \\
2014 & 3,19 & 2,16 & 1,15 & 0,50 & 0,12 \\
2015 & 0,06 & 1,49 & 2,12 & 0,74 & 0,70 \\
2016 & 2,12 & 1,86 & 0,02 & 0,04 & 0,15 \\
2017 & 1,51 & 0,01 & - & 0,05 & 0,10 \\
2018 & 1,04 & 0,03 & - & 0,05 & 0,05 \\
2019 & 2,40 & 0,02 & - & 0,12 & 0,01 \\
Rata-Rata & 4,64 & 3,57 & 8,50 & 1,68 & 3,68 \\
\hline
\end{tabular}

The average RCA value for Indonesian Cocoa Beans in Malaysia, Singapore, China, Germany, and the USA is> 1, which means that Indonesia has a comparative advantage for cocoa beans and has strong competitiveness. The value of RCA> 1 means that the share of cocoa beans in the export of all Indonesian commodities is greater than the share of cocoa in the exports of all commodities of all countries. The highest value of RCA Cocoa Beans Indonesia in Malaysia, Singapore, China, Germany, and the USA was achieved in 2010 and decreased in 2011-2019. It is because since 2010, there has been a new regulation, Permenkeu No. 67 / PMK.011 / 2010, concerning the export duty policy for cocoa beans. This is following the opinion of Suryana et al. (2014) which states that regulation No. 67 / PMK011 / 2010 stated that starting in 2010, Indonesia implemented a policy of up to $15 \%$ export duty for cocoa beans which aims to grow the domestic cocoa processing industry which will increase exports of processed cocoa products that are competitive and shift from cocoa beans to processed cocoa products.

Table 2. The RCA Value of Indonesian Cocoa Butter in Export Destination Countries in 2010-2019

\begin{tabular}{rlllll}
\hline \hline Tahun & \multicolumn{5}{c}{ Nilai RCA } \\
& Malaysia & Singapura & China & Jerman & USA \\
\hline 2010 & - & 2,48 & 0,12 & 3,96 & 21,33 \\
2011 & 10,76 & 0,77 & 28,74 & 4,42 & 34,68 \\
2012 & 8,48 & 3,41 & 15,10 & 26,63 & 40,04 \\
2013 & 16,52 & 5,13 & 9,40 & 21,71 & 42,29 \\
2014 & 20,57 & 4,27 & 28,08 & 28,56 & 48,59 \\
2015 & 21,66 & 2,54 & 30,59 & 26,86 & 50,91 \\
2016 & 20,66 & 1,14 & 23,57 & 39,59 & 49,78 \\
2017 & 12,66 & 0,06 & 22,83 & 16,97 & 57,81 \\
2018 & 11,85 & 0,95 & 29,77 & 27,00 & 71,63 \\
2019 & 14,75 & 0,71 & 21,76 & 21,52 & 50,77 \\
Rata-rata & 15,32 & 2,14 & 20,99 & 21,72 & 46,78 \\
\hline
\end{tabular}

The average RCA value for Indonesian Cocoa Butter in Malaysia, Singapore, China, Germany, and the USA> 1, which means that it has a comparative advantage wherein 2011 - 2019 it has increased even though it fluctuates compared to 2010. The RCA value> 1 means the share of cocoa butter in exports all Indonesian commodities are greater than the share of cocoa in the exports of all 
commodities of all countries. The RCA value of cocoa butter is the highest among the RCA for cocoa beans and other preparations. The reason is that cocoa butter has a higher melting rate so that it is preferred by consumers, just like Towaha's (2017) opinion which states that cocoa butter is a product of cocoa that has the largest proportion of processed cocoa export volume in Indonesia. The cocoa butter industry had developed long before the introduction of the export tax policy, so it developed further after its implementation.

Table 3. The RCA Value of Indonesian Cocoa Pasta in Export Destination Countries in 2010-2019

\begin{tabular}{crrrrr}
\hline \hline Tahun & \multicolumn{5}{c}{ Nilai RCA } \\
& Malaysia & Singapura & China & Jerman & USA \\
\hline 2010 & 0,36 & 6,35 & 53,13 & 89,70 & 2,10 \\
2011 & 5,62 & 0,02 & 61,60 & 62,86 & 28,66 \\
2012 & 7,47 & 0,01 & 61,69 & 275,21 & 65,97 \\
2013 & 20,67 & 3,14 & 12,62 & 105,48 & 33,88 \\
2014 & 21,50 & 0,07 & 2,27 & 116,74 & 25,22 \\
2015 & 11,19 & - & 6,71 & 108,28 & 36,14 \\
2016 & 24,41 & 1,74 & - & 181,99 & 39,57 \\
2017 & 21,03 & 2,08 & 0,23 & 1,04 & 24,56 \\
2018 & 21,55 & 1,07 & - & 0,15 & 45,19 \\
2019 & 15,66 & 2,55 & 0,27 & 0,18 & 35,87 \\
Rata-rata & 14,95 & 1,69 & 19,85 & 94,16 & 33,72 \\
\hline
\end{tabular}

The RCA value has increased then decreased, but the average RCA value is $>1$, which means it has a comparative advantage. The value of RCA $>1$ means that the share of cocoa pasta in exports of all Indonesian commodities is greater than the share of cocoa in exports of all commodities of all countries. The implementation of the Indonesian government's export tax policy is going well because Indonesia can shift from being a majority of cocoa exporters in the form of cocoa beans to being in the form of cocoa processing such as exporting cocoa paste. In addition, the development of cocoa paste exports can be further increased.

Table 4. Value of RCA Cocoa Powder Indonesia in export destination countries in 20102019

\begin{tabular}{crrrrr}
\hline \hline Tahun & \multicolumn{5}{c}{ Nilai RCA } \\
& Malaysia & Singapura & China & Jerman & USA \\
\hline 2010 & 5,81 & 1,17 & 13,81 & 0,63 & 1,58 \\
2011 & 6,34 & 1,86 & 10,49 & 0,31 & 1,49 \\
2012 & 6,14 & 2,59 & 12,27 & 9,26 & 2,16 \\
2013 & 5,53 & 0,98 & 12,05 & 21,21 & 1,27 \\
2014 & 5,72 & 0,25 & 13,26 & 38,98 & 0,89 \\
2015 & 7,96 & 0,27 & 17,34 & 23,36 & 1,26 \\
2016 & 13,87 & 1,69 & 14,77 & 8,24 & 3,26 \\
2017 & 16,66 & 2,27 & 11,58 & 0,10 & 1,93 \\
2018 & 17,05 & 1,37 & 10,48 & - & 2,88 \\
2019 & 12,73 & 0,95 & - & - & 2,87 \\
Rata-rata & 9,78 & 1,34 & 12,89 & 12,76 & 1,86 \\
\hline
\end{tabular}

The average value of RCA> 1, which means it has a comparative advantage. The value of RCA> 1 means that the share of cocoa powder in exports of all Indonesian commodities is greater than the share of cocoa in exports of all commodities of all countries. The largest average RCA value for cocoa powder among the five destination countries, China.
It is supported by Kiranta and Meydianawathi research (2014) which states that China's rapid growth and development requires a lot of cocoa commodities, making this a great opportunity for Indonesia when it is related to the prospect of Indonesia's increasing cocoa exports, then Indonesia's opportunity to dominate the market will get bigger.

\section{Export Product Dynamic (EPD)}

Table 5. EPD Value of Cocoa Beans Indonesia in destination countries in 2010-2019

\begin{tabular}{|c|c|c|c|}
\hline No & $\begin{array}{l}\text { Negara Tujuan } \\
\text { Ekspor }\end{array}$ & $\begin{array}{c}\text { Nilai } \\
\text { EPD X }\end{array}$ & $\begin{array}{c}\text { Nilai } \\
\text { EPD Y Keterangan }\end{array}$ \\
\hline \multicolumn{4}{|c|}{-----------\%----------- } \\
\hline 1. & $\mathrm{Mal}$ & $-0,00741$ & $-0,00015 R$ \\
\hline 2. & Singapura & $-0,00514$ & $-0,00012$ Retr \\
\hline 3. & China & $-0,01108$ & $-0,00004$ Retreat \\
\hline 4. & Jerman & $-0,00048$ & $-0,00001$ Retreat \\
\hline 5. & USA & $-0,00358$ & $-0,00006$ Retreat \\
\hline
\end{tabular}
destination countries, the market position for cocoa beans in 2010-2019 in Malaysia, Singapore, China, Germany, and the USA is in the position of Retreat. This position means that the market condition is no longer desirable because the export market share of Indonesian cocoa beans in that country is lower than the average growth of the world export market share, where there has been a decline in demand in that country.

Table 6. EPD Value of Indonesian Cocoa Butter in destination countries in 2010-2019

\begin{tabular}{lcccc}
\hline \hline No & $\begin{array}{c}\text { Negara Tujuan } \\
\text { Ekspor }\end{array}$ & $\begin{array}{c}\text { Nilai } \\
\text { EPD X }\end{array}$ & $\begin{array}{c}\text { Nilai } \\
\text { EPD Y }\end{array}$ & Keterangan \\
\hline & & $--------\%$ & $----------~$ \\
1. & Malaysia & 0,00655 & $-0,00015$ & Falling star \\
2. & Singapura & $-0,00116$ & $-0,00012$ & Retreat \\
3. & China & 0,00407 & $-0,00004$ & Falling star \\
4. & Jerman & 0,00036 & $-0,00001$ & Falling star \\
5. & USA & 0,00233 & $-0,00006$ Falling star \\
\hline
\end{tabular}

According to EPD calculations in export destination countries, the market position for cocoa butter in 2010-2019 in Malaysia, China, Germany, and the USA is in a falling star position. This position means that the market share for cocoa butter has increased but the product is not dynamic or tends to be stagnant, where the share of product exports has decreased and the share of the country's exports as a whole has experienced positive growth. Export growth to this country has increased but there is no increase in demand in that country. This position means that Indonesia still has the opportunity to develop the export market for cocoa butter in that country. The market position for cocoa butter in Singapore is at the Retreat position. This position means that the market condition is no longer desirable because the export market share of 
Indonesia's cocoa butter growth is lower than the average growth of the world export market share, so it can be said that the export of cocoa butter is not competitive. The conditions for retreat and falling star on cocoa butter indicate the need for innovation, research, and development as well as better marketing in the share of cocoa butter export.

Table 7. EPD Value of Indonesian Cocoa Pasta in destination countries in 2010-2019

\begin{tabular}{|c|c|c|c|}
\hline No & $\begin{array}{l}\text { Negara } \\
\text { Tujuan } \\
\text { Ekspor }\end{array}$ & $\begin{array}{l}\text { Nilai } \\
\text { EPD X }\end{array}$ & $\begin{array}{l}\text { Nilai } \\
\text { EPD Y }\end{array}$ \\
\hline & \multicolumn{3}{|c|}{-----------\%---------- } \\
\hline 1. & Malaysia & 0,00724 & $-0,00015$ Falling star \\
\hline 2. & Singapura & 0,00121 & -0,00012 Falling star \\
\hline 3. & China & $-0,01$ & -0,00004 Retreat \\
\hline 4. & Jerman & $-0,00305$ & $-0,00001$ Retreat \\
\hline 5. & USA & 0,00282 & -0.00006 Falling star \\
\hline
\end{tabular}

Based on EPD calculations in export destination countries, the market position for Cocoa Pasta in 2010-2019 in Malaysia, Singapore, and the USA are in a Falling star position. This position means that the market share for cocoa pasta has increased but the product is not dynamic or tends to be stagnant, where the share of product exports has decreased while the share of the country's exports as a whole has experienced positive growth. This position means that Indonesia still has the opportunity to develop the export market for cocoa pasta in that country. However, the market position for cocoa pasta in China and Germany is in the position of Retreat. This position means that the market condition is no longer desirable because the export market share of Indonesia's cocoa pasta growth is lower than the average growth of the world export market share, so it can be said that the export of cocoa pasta is not competitive.

Table 8. EPD Value of Indonesian Cocoa Powder in destination countries in 2010-2019

\begin{tabular}{llrl}
\hline \hline No & \multicolumn{4}{l}{ Negara Tujuan Nilai } & \multicolumn{2}{l}{ Nilai } & Keterangan \\
& Ekspor & EPD X & \multicolumn{1}{l}{ EPD Y } \\
\hline & & $---------\%$ & ---------- \\
1. & Malaysia & 0,00234 & $-0,00015$ Falling star \\
2. & Singapura & $-0,00038$ & $-0,00004$ Retreat \\
3. & China & $-0,00071$ & $-0,00012$ Retreat \\
4. & Jerman & -0.00002 & $-0,00001$ Retreat \\
5. & USA & $-0,00009$ & $-0,00007$ Retreat \\
\hline
\end{tabular}

Based on the EPD calculation in the export destination country, the market position for cocoa Powder in 2010-2019 in Malaysia is in the position of falling star. This position means that the market share for cocoa powder has increased but the product is not dynamic or tends to be stagnant, where the share of product exports has decreased while the share of the country's exports as a whole is experiencing positive growth. This position means that Indonesia still has the opportunity to develop the export market for cocoa powder in that country. However, the market position for cocoa powder in Singapore, China, Germany, and the USA is at the Retreat position. This position means that the market condition is no longer desirable because the export market share of Indonesian cocoa paste growth is lower than the average growth of the world export market share, so it can be said that the export of cocoa powder is not competitive.

\section{Trend Analysis}

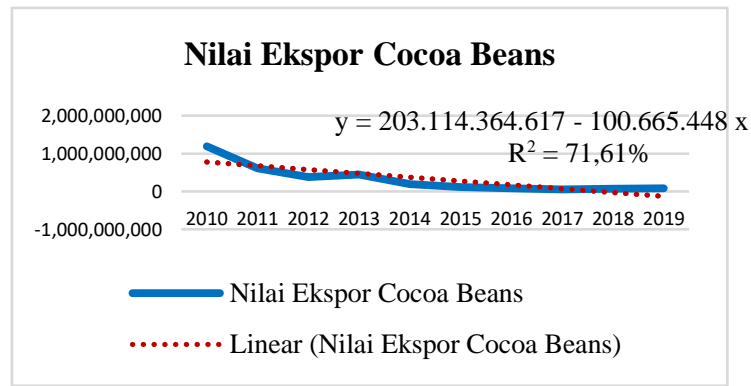

Graph 1. Export Value of Cocoa Beans in 2010 $-2019$

The trend of the export value of Indonesian cocoa beans in 2010 - 2019 shows a negative slope (decreasing). In the linear trend graph, the export value of Indonesian cocoa beans has the same model, $y=203,114,364,617-100,665,448 x$. The model has an estimate that every year, the value of exports has decreased by $\$ 100,665,448$.

The following table shows the results of forecasting the export value of Indonesian cocoa beans for the next five years (2020-2024), based on the equation: $y=203,114,364,617-100,665,448 x$.

Table 9. Forecasting Results for Cocoa Beans

\begin{tabular}{cc}
\hline \hline Tahun & Peramalan Nilai $\mathbf{( \$ )}$ \\
\hline 2020 & -229.840 .049 \\
2021 & -330.505 .497 \\
2022 & -431.170 .945 \\
2023 & -531.836 .393 \\
2024 & -632.501 .841 \\
\hline
\end{tabular}

Source: Processed data

The results above show that the export value of cocoa beans for the next five years is predicted to continue to decline, which in 2020 is worth $\$$ $229,840,049$ until 2024 reaches $\$-632,501,841$. It shows that in the next five years, the export of Indonesian cocoa beans is expected to decline because the export value will continue to decline. 


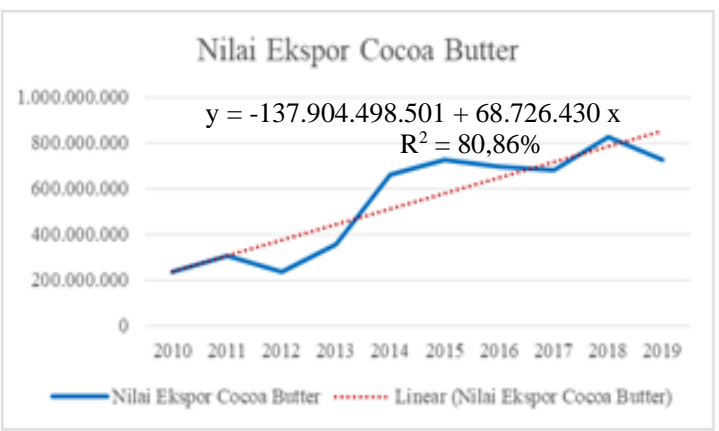

Graph 2. Export Value of Cocoa Butter in $2010-$ 2019

The trend of Indonesia's cacao butter export value in 2010-2019 shows a positive (increasing) slope. In the linear trend graph, the export value of Indonesia's cocoabutter has a model equation, $\mathrm{y}=$ $137,904,498,501+68,726,430 \mathrm{x}$. The model has an estimate that every year, the value of exports has increased by $\$ 68,726,430$. The following table shows the results of forecasting the export value of Indonesian cocoa butter for the next five years (2020-2024), based on the equation: $\mathrm{y}=$ $137,904,498,501+68,726,430 \mathrm{x}$.

Table 10. Forecasting Results for cocoa butter

\begin{tabular}{cc}
\hline \hline Tahun & Peramalan Nilai (\$) \\
\hline 2020 & 922.889 .891 \\
2021 & 991.616 .321 \\
2022 & 1.060 .342 .751 \\
2023 & 1.129 .069 .180 \\
2024 & 1.197 .795 .610 \\
\hline
\end{tabular}

Source: Processed data

The results above indicate that the export value of cocoa butter is predicted to continue to increase in the next five years. Where in 2020 a value of $\$ 922,889,891$ until 2024 reached $\$$ $1,197,795,610$. It shows that in the next five years Indonesia tends to export cocoa butter in quite a large amount because it has an increasing export value so it can benefit the country.

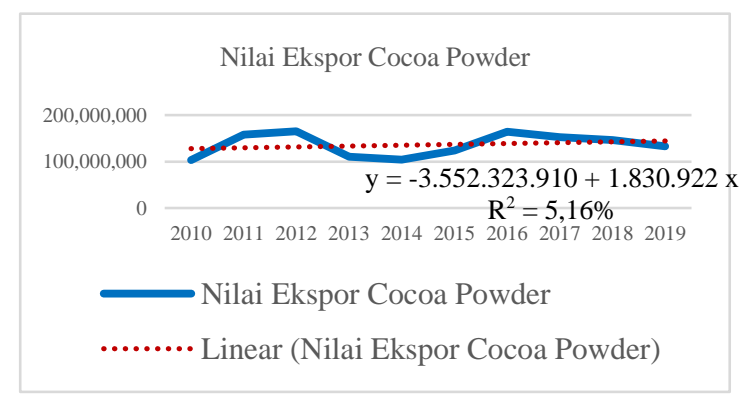

Graph 3. Export Value of Cocoa Powder in 2010 - 2019

The trend of Indonesia's cacao powder export value in 2010-2019 shows a positive (increasing) slope. In the linear trend graph, the export value of Indonesian cacao powder has the same model, $\mathrm{y}=$ -
$3,552,323,910+1,830,922 \mathrm{x}$. The model has an estimate that every year, the value of exports has increased by $\$ 1,830,922$. The following table shows the results of forecasting the export value of Indonesian cocoa powder for the next five years (2020-2024), based on the equation: $\mathrm{y}=$ $3,552,323,910+1,830,922 \mathrm{x}$.

Table 11. Forecasting Results for cocoa powder

\begin{tabular}{cc}
\hline \hline Tahun & Peramalan Nilai (\$) \\
\hline 2020 & 146.139 .020 \\
2021 & 147.969 .942 \\
2022 & 149.800 .864 \\
2023 & 151.631 .787 \\
2024 & 153.462 .709 \\
\hline
\end{tabular}

Source: Processed data

The results above indicate that the export value of cocoa powder over the next five years is predicted to continue to increase. Where in 2020 a value of $\$ 146,139,020$ until 2024 reached $\$$ $153,462,709$. It shows that in the next five years, Indonesia will tend to export cocoa powder in large enough quantities because it has an increasing export value so it can benefit the country.

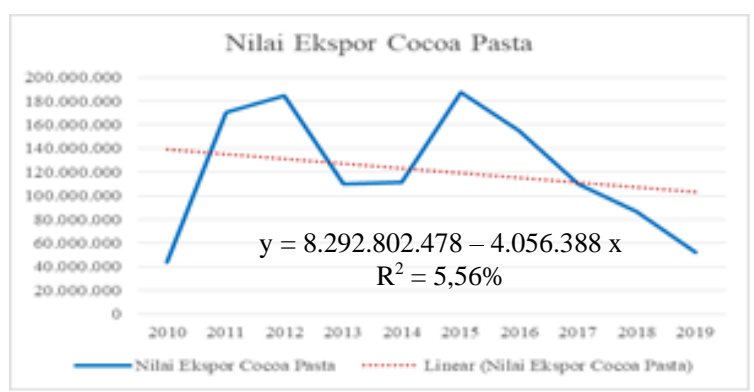

Graph 4. Export Value of Cocoa Pasta in 2010 $-2019$

The export value trend of Indonesian cocoa pasta in 2010-2019 shows a negative slope (decreasing). In the linear trend graph, the export value of Indonesian cocoa paste has the same model, $\mathrm{y}=8,292,802,478-4,056,388 \mathrm{x}$. The model has an estimate that every year, the value of exports has decreased by $\$ 4,056,388$. The following table shows the results of forecasting the export value of Indonesian cocoa paste for the next five years (20202024), based on the equation: $y=8,292,802,478$ $4,056,388 \mathrm{x}$.

Table 12. Forecasting Results for cocoa paste

$\begin{array}{cc}\text { Tahun } & \text { Peramalan Nilai } \mathbf{( \$ )} \\ 2020 & 98.898 .044 \\ 2021 & 94.841 .656 \\ 2022 & 90.785 .268 \\ 2023 & 86.728 .879 \\ 2024 & 82.672 .491\end{array}$

Source: Processed data

The above results indicate that the export value of cocoa paste over the next five years is predicted to continue to decline. Where in 2020 it is 
valued at \$98,898,044 until 2024 it reaches \$ $82,672,491$. It shows that even though its value will decline in the next five years, Indonesia still tends to export cocoa pasta because it has a positive export value so it can benefit the country.

\section{CONCLUSION}

Comparative analysis using the RCA method shows that the commodities of Indonesian cocoa beans, cocoa butter, cocoa paste, and cocoa powder in 2010-2019 have an RCA value> 1, which means they are competitive and have a comparative advantage in destination countries, such as Malaysia, Singapore, China, Germany, and the USA. Competitive analysis using the EPD method shows that the commodities of cocoa beans, cocoa butter, cocoa paste, and Indonesian cocoa powder in 2010-2019 have EPD retreat and falling star values. The EPD value of cocoa beans to Malaysia, Singapore, China, Germany, and the USA experienced a retreat. The EPD value of cocoa butter to Malaysia, China, Germany, and the USA experienced a falling star, while Singapore experienced a retreat. The EPD value of cocoa pasta to Malaysia, Singapore, and the USA experienced a Falling star, while China and Germany experienced a retreat. The EPD value of cocoa powder to Malaysia experienced a falling star while Singapore, China, Germany, and the USA experienced a retreat. The linear trend analysis shows that the export value of Indonesian cocoa beans in 2020-2024 is predicted to continue to decline because the total value of Indonesian cocoa bean exports to the world has decreased from 2010-2019. The export value of Indonesian cocoa butter and cocoa powder in 20202024 is predicted to continue to increase due to the increase in total export value in 2010-2019. Finally, the export value of Indonesian cocoa pasta in 20202024 is predicted to increase then decrease because the export value of Indonesian cocoa pasta to the world has increased from 2010-2015 and has decreased from 2016-2019.

\section{Suggestion}

To increase the production of cocoa beans in Indonesia, the government and business actors must increase the development of the downstream industry in cocoa beans. To increase the production of industrially processed cocoa, there must be a cooperation between the government and business actors regarding quality facilities and infrastructure. To increase the competitiveness of cocoa, Indonesia needs to maintain the quality and quantity of cocoa beans and processed products by paying attention to export stability and ensuring the availability of raw materials for processed cocoa products, cocoa beans. To obtain more reliable research results, research can be carried out using other analytical methods or other data sources to see further how the competitiveness capabilities and capabilities of Indonesia's cocoa export development prospects.

\section{REFERENCES}

Amalina. A.A.F., Novianti, T dan Asmara, A. 2018. Analisis kinerja perdagangan ke negara potensian benua afrika. J. Ekonomi dan Kebijakan Pembangunan, 7(1), 43-59.

Badan Pusat Statistik (BPS). 2018. Statistik Kakao Indonesia 2017. https://www.bps.go.id. Diakses pada 25 Desember 2018.

Ghozy, M.R.A., Soelistyo, A., dan Kusuma, H. 2017. Analisis ekspor kakao Indonesia di pasar internasional. J.Ekonomi, 1(4), 453473.

Hasibuan, A.M., Nurmalina, R., dan Wahyudi, A. 2012. Analisis kinerja dan daya saing perdagangan biji kakao dan produk kakao olahan indonesia di pasar internasional. J. RISTRI, 3(1), 57-70.

Kiranta, F. dan Meydianawathi, L. G. 2014. Analisis tingkat daya saing ekspor biji kakao indonesia tahun 2007-2012. J. Ekonomi Pembangunan UNUD, 3(11), 502-512.

Suryana, A.T., Fariyanti, A., dan Rifin, A. 2014. Analisis perdagangan kakao indonesia di pasar internasional. J. Tanaman Industri dan Penyegar, 1(1), 29-40.

Towaha, J. 2012. Diversifikasi Produk Kakao sebagai Bahan Baku Biofarmaka. Balai Penelitian Tanaman Industri dan Penyegar. Hal. 141-154. 
This page is intentionally left blank 